\title{
Anatomical evaluation of the cervical vertebrae of Wistar rats by means of digital radiographs and its correlation with the maturation stages of human cervical vertebrae
}

\author{
Roberto Hiroshi Matsui ${ }^{1}$, Julio Cezar de Melo Castilho², Luiz César de Moraes ${ }^{3}$, \\ Mônica Fernandes Gomes ${ }^{4}$ Kurt Faltin Júnior ${ }^{5}$, Miriam Yumi Matsuí
}

Introduction: Biological age is an important parameter for growth and development assessment. It can be evaluated through the observation of radiographic changes in skeletal maturation of cervical vertebrae. Objective: This study aims to: a) verify if there is correlation between growth curve and the stages of bone age of animals used in laboratories, by evaluating radiographs of the cervical vertebrae; b) correlate these stages with their correspondents in humans. Methods: 35 Wistar rats were evaluated for a period of 160 days, starting at day 22nd (weaning), with cross sections for periodic weighing, length measurement and digital radiography. Radiographs of the cervical vertebrae (C2 and C3) were measured by means of a computer program (Radio IMP). Data were submitted to statistical analysis (ANOVA) and Pearson correlation. Results: Growth spurt was characterized by fast increasing in weight and length. Through ANOVA, differences were observed in the cervical measurements between days 22, 97, 127, 157, 187 and 217 ( $\mathrm{p}<0.001)$. A high correlation was found between increasing in body length and weight, as well as in cervical vertebrae height $(\mathrm{r}=0.86)$. Increments in concavities of vertebrae were also observed, similar to humans. Conclusions: There is correlation between body growth and maturation of cervical vertebrae in rats. Despite the continuous development of concavities, it was not possible to clearly identify the $5 / 6$ stages as in studies of cervical vertebrae maturation in humans.

Keywords: Growth and development. Cervical vertebrae. Radiography.

Introdução: a idade biológica é um parâmetro importante na avaliação do crescimento e desenvolvimento, podendo ser avaliada por meio da observação de alterações na maturação óssea das vértebras. Objetivo: o presente estudo visa descrever e relacionar a curva de crescimento de ratos utilizados em pesquisas laboratoriais com os estágios de idade óssea, avaliados por radiografias de vértebras cervicais, e correlacionar esses estágios com estudos correspondentes em humanos. Métodos: foram avaliados 35 ratos Wistar em um período de 160 dias, iniciando no $22^{\circ}$ dia de vida (desmame), com cortes transversais periódicos para pesagem, medição do comprimento e radiografias digitais. As radiografias das vértebras cervicais ( $\mathrm{C} 2$ e C3) foram mensuradas por meio de um programa de computador (Radio IMP). Os dados foram submetidos à análise estatística de variância (ANOVA). Resultados: o surto de crescimento caracterizou-se por aumento rápido de peso e comprimento, seguido por um período de crescimento lento e de estabilidade. Uma alta correlação $(r=0,86)$ foi verificada entre o aumento de peso e o comprimento do corpo, bem como o comprimento das vértebras cervicais. Incrementos nas concavidades das vértebras dos ratos foram observados, semelhantemente aos resultados obtidos em estudos em humanos. Conclusões: existe correlação entre o crescimento corporal de ratos e a maturação das vértebras cervicais. Apesar da detecção de desenvolvimento contínuo de concavidades das vértebras, não foi possível identificar claramente os 5 ou 6 estágios de maturação óssea descritos em seres humanos.

Palavras-chave: Crescimento e desenvolvimento. Vértebras cervicais. Radiografia.

" The authors report no commercial, proprietary or financial interest in the products or companies described in this article.

\footnotetext{
${ }^{1}$ Assistant Professor, Orthodontics and Dentofacial Orthopedics, UNIP.

${ }^{2}$ Associate Professor, Diagnosis and Surgery, UNESP.

${ }^{3}$ Professor, Diagnosis and Surgery, UNESP.

${ }^{4}$ Associate Professor, Oral Pathology, Biosciences and Oral Diagnosis, UNESP.

${ }^{5}$ Full Professor, Orthodontics and Dentofacial Orthopedics, UNIP.

${ }^{6}$ Master student, Oral Pathology, UNESP.
}

How to cite this article: Matsui RH, Castilho JCM, Moraes LC, Gomes MF, Faltin Júnior K, Matsui MY. Anatomical evaluation of the cervical vertebrae of Wistar rats by means of digital radiographs and its correlation with the maturation stages of human cervical vertebrae. Dental Press J Orthod. 2013 JulyAug;18(4):82-8.

Submitted: January 13, 2011 - Revised and accepted: December 03, 2011

Contact address: Roberto Hiroshi Matsui

Av. Santa Catarina, 1825 - CEP: 04378-300 - São Paulo / SP, Brazil

E-mail : matsuirh@hotmail.com 


\section{INTRODUCTION}

The understanding of facial growth is indispensable to the orthodontic and orthopedic treatment planning. Treatment of skeletal, dental and muscular discrepancies should focus on mixed dentition, preferably before completion of second dentition ${ }^{1}$. Since the development of structures of stomatognathic system occurs simultaneously with the body growth, ${ }^{2}$ the comprehension of the process of growth as a whole, by studying its moments of peaks and stability, is essential.

Obtaining information concerning growth includes the use of laboratory animals. It would not be the ideal though, to compare the effects of proposed therapies for patients with mixed dentition using adult rats. Ideally, they should be studied in the corresponding phases of human growth, so that treatment effects can be evaluated and compared.

This concern about correlating humans and animals according to age is present in recent studies. ${ }^{3}$ In order to understand the influence of age on the efficacy of therapies with stem cells, the authors compared stem cell markers in younger (4 months) and older (15 months) rats, suggesting correlation between their findings and therapies in elderly patients.

Besides the use of chronological age, evaluating biological age of humans and animals undergoing growth is also important to establish reliable correlations between them.

The growth process can be assessed by changes in the morphology of different bones during its maturation. ${ }^{4,5}$

The comparison between chronological age and bone age (by means of lateral cephalometric and carpal radiographs) shows that chronological age of a person does not always precisely correlate with the bone age. The latter may present himself advanced or delayed in relation to the first. ${ }^{6,7,8}$

Besides the assessment of cervical vertebrae maturation $^{9,10,11}$ and skeletal maturation of the hand and wrist, ${ }^{12,13}$ several other methods for measurement of age are studied and compared, such as dental age, ${ }^{14}$ variations in height and weight, ${ }^{4}$ mandibular growth ${ }^{15,16}$ and expression of secondary sexual characteristics, ${ }^{17,18}$ each of them used according to the interests of diagnosis.

The cervical vertebrae maturation (CVM) in humans can be classified in five stages (CVM I to V) ${ }^{19}$ or six stages (initiation, acceleration, transition, deceleration, and final maturation). ${ }^{20}$ This evaluation method is statistically valid and reliable, ${ }^{19,20,21}$ presenting the same clinical value to the evaluation of hand and wrist. The inherent advantage of this method would be eliminating the need for radiographs other than those that comprise regular orthodontic exams.

Often the stages of growth and development are studied in laboratory animals based on chronological age. ${ }^{22}$ There are, however, no studies evaluating radiographic stages of bone development and its correlation with the development of cervical vertebrae during the pubertal growth in humans.

Thus, this study aimed: 1) to observe, by means of digital radiographs, the anatomical stages of maturation of cervical vertebrae 2 and 3 (C2 and C3) of animals (Wistar rats) during growth, correlating bone age with chronological age, weight and length; and 2) compare cervical vertebrae maturation stages in rats and in humans.

\section{MATERIAL AND METHODS}

\section{Ethical aspects}

Approval was obtained from the Ethics Committee of Research Involving Animals, School of Dentistry, UNESP-São José dos Campos, protocol 046/2007-PA/CEP.

\section{Characteristics of the animals}

Thirty five Wistar rats (Rattus norvegicus albinus), 20 males and 15 females, were supplied by the vivarium of the School of Dentistry, Universidade Estadual Paulista Julio de Mesquita Filho, Campus de São José dos Campos - SP.

The study started after weaning of the animals and with the introduction of solid food diet at 22 days after birth. At this phase, their weight was approximately 80-100 grams. The animals were kept in cages, each with five rats in light-dark cycle of 12 hours with controlled temperature and humidity and fed with a balanced diet (Labina ${ }^{\circledR}$, Guabi - Guabinutrilabor for rats and mice) and water ad libitum.

The animals were treated with single doses of polyvalent anthelmintic (Zentel ${ }^{\circledR}$, São Paulo, Brasil) and multivitamin (Vita Gold Potenciado ${ }^{\circledR}$, Tortuga Companhia Zootécnica Agrária, São Paulo, Brasil), 40 drops per liter of solution for 5 days.

Completed the periods of observation, the animals were sacrificed by overdose of anesthetic. 


\section{Periods of observation}

Considering that within 1.5 months, rats reach their puberty, and after 6 months, they reach maturity, ${ }^{23}$ a wide age range was included taking in consideration the need of observation from the initial to the final phase of growing.

All animals were examined 22 days after birth and thereafter, every 14 days until the observation of growth peak. After that, exams were done every 29 days, until the completion of maturity phase and adulthood (160 days), totaling nine acquisitions of radiographic images per animal.

Since rats were observed for more than 7 months, the observation period of this studied included: weaning, puberty and maturity.

In adulthood, each rat month is approximately equivalent to 2.5 human years. ${ }^{24}$ It was considered that main changes are expected to happen during the growth peak, explaining the higher frequency of examination during this period.

\section{Preparation of the animals for X-ray analysis}

After weighing, the animals were anesthetized with a combination of ketamine chloride (Vetaset ${ }^{\circledR}$, Fort Dodge Animal Health Fort Dodge, Iowa, USA) dose of $5 \mathrm{mg} / \mathrm{kg}$, associated with xylazine (Rompum $^{\circledR}$, Bayer S.A. - Saúde Animal, São Paulo, Brazil), sedative, analgesic and muscle relaxant at a dose of $10 \mathrm{mg} / \mathrm{kg}$, administered intramuscularly.

\section{RADIOGRAPHIC ANALYSIS}

\section{Protocol of image acquisition of}

the cervical vertebrae

A wooden table, especially made for this purpose, was adapted for the positioning of the animal in a niche excavated to accommodate the sensor (Fig 1). After immobilization and positioning of the rat through this positioner, a digital radiography was obtained using the system Visualix Gx-S-HDI (Gendex Dental System, Dentsply International, Chicago, IL, USA). This system captures digital radiographic image by means of a CCD sensor (Charge-Coupled Device), with active area of $20.0 \mathrm{~mm}$ (width) x $30.0 \mathrm{~mm}$ (length). The Xray machine used was Gendex 765 DC (Gendex Dental X-Ray Division, Dentsply International Inc., IL, USA), set to $65 \mathrm{KVp}$ and $7 \mathrm{~mA}$. The rats were placed on the sensor positioned parallel to the ground with the central beam of X-rays directed perpendicular to the table. The focus-object distance was $40 \mathrm{~cm}, 90 \mathrm{de}-$ gree angle of incidence and duration of exposure to Xrays of 0.01 seconds. The digital radiographic images were stored in JPEG file format.

\section{Anatomical analysis of cervical vertebrae in rats}

The animals were followed-up until the final phase of growth (160 days). Each animal had a chart and spreadsheet for analysis of the maturation of cervical vertebrae (C2 and C3) and other growth indices such as body length, weight, chronological age, for comparison of stages of development and growth.

In order to evaluate the growth and anatomical changes of the vertebrae, the diameter, height, width and area were measured and calculated (Fig 2).

The analysis of maturation of cervical vertebrae (C2 and C3) of animals was performed based on the method of Hassel and Farman ${ }^{20}$ summarized in Table 1 and schematically shown in Figure 3. The following changes were made to this method: it was used digital radiography and the cervical vertebrae was measured with the Radio IMP software (Radiocef).

\section{Analysis of body length and weight of rats}

The body length was measured by a metal rule (Tramontina, RS, Brazil) in millimeters, from the

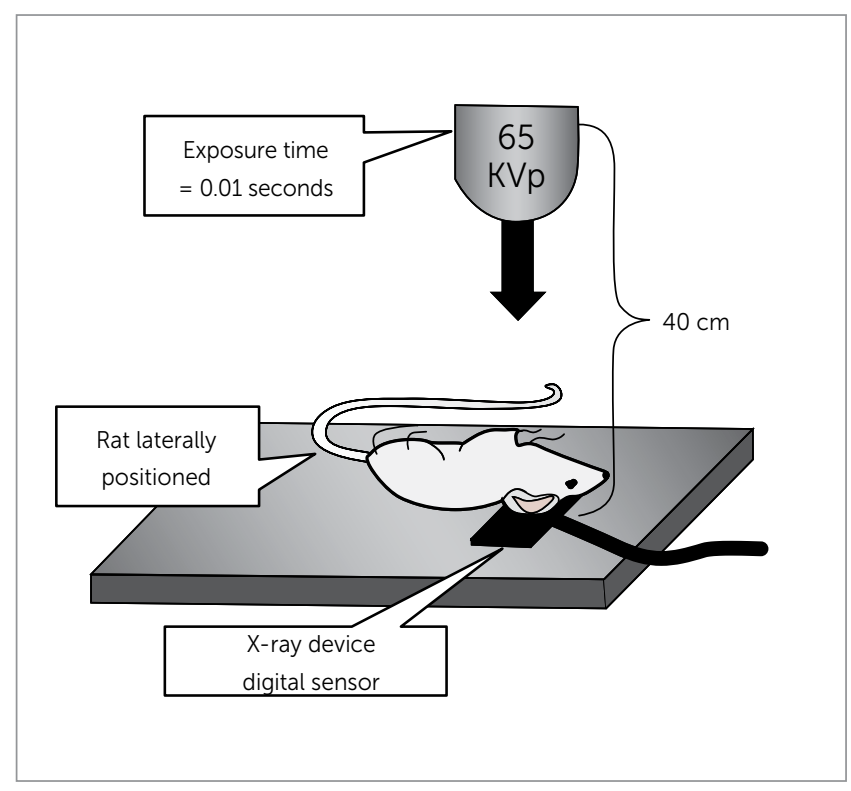

Figure 1 - Schematic representation of radiographs taken using the Visualix GX-S-HDI system. 


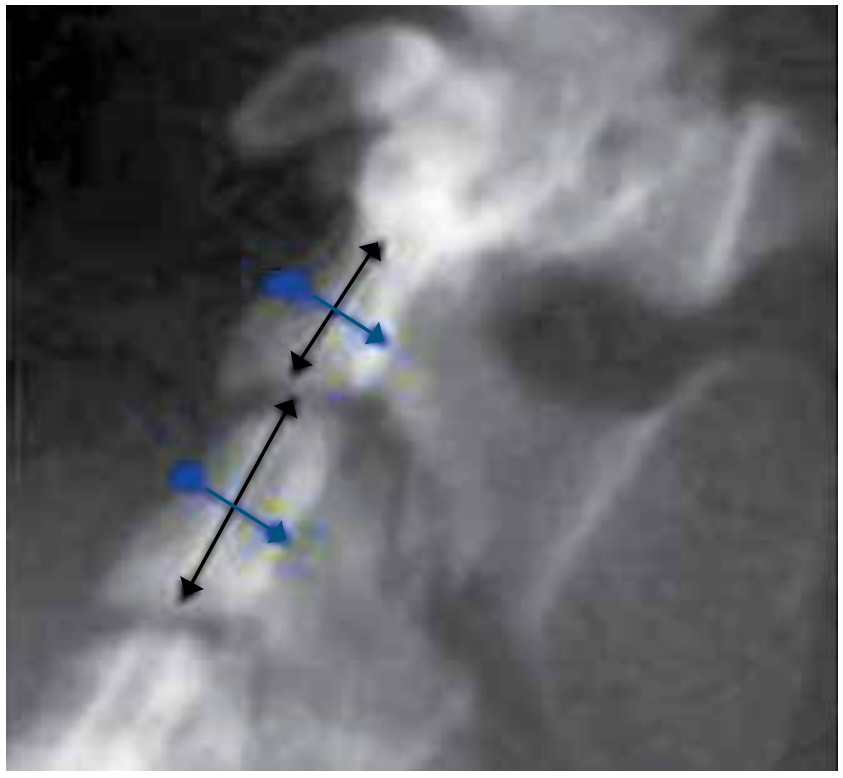

Figure 2 - Digital radiography in lateral view of cervical vertebrae (C2 and C3) of adult rat, for linear measurement.
Table 1 - Maturation stage of cervical vertebrae.

\begin{tabular}{|c|c|c|c|}
\hline Stage & $\begin{array}{l}\text { Growing } \\
\text { activity }\end{array}$ & Inferior margin & $\begin{array}{l}\text { Vertebrae } \\
\text { morphology }\end{array}$ \\
\hline Initiation & High & Flat (C2, C3, C4) & Triangular \\
\hline Acceleration & High & $\begin{array}{c}\text { Concavity (C2 and C3) } \\
\text { Flat (C4) }\end{array}$ & $\begin{array}{c}\text { Rectangular (C3) } \\
\text { (width> height) }\end{array}$ \\
\hline Transition & Moderate & $\begin{array}{l}\text { Apparent concavity } \\
\text { (C2 and C3) } \\
\text { Initial concavity (C4) }\end{array}$ & $\begin{array}{c}\text { Rectangular } \\
\text { (width> height) } \\
\text { (C3, C4) }\end{array}$ \\
\hline Deceleration & Low & $\begin{array}{l}\text { Apparent concavity } \\
\text { (C2, C3 and C4) }\end{array}$ & $\begin{array}{l}\text { Squared } \\
(\mathrm{C} 3, \mathrm{C} 4)\end{array}$ \\
\hline Maturation & Insignificant & $\begin{array}{l}\text { Accentuated concavity } \\
\text { (C2, C3 and C4) }\end{array}$ & $\begin{array}{l}\text { Squared } \\
(\mathrm{C} 3, \mathrm{C} 4)\end{array}$ \\
\hline Final & Completed & $\begin{array}{l}\text { Deep concavity } \\
\text { (C2, C3 and C4) }\end{array}$ & $\begin{array}{c}\text { Rectangular } \\
\text { (height > width) }\end{array}$ \\
\hline
\end{tabular}

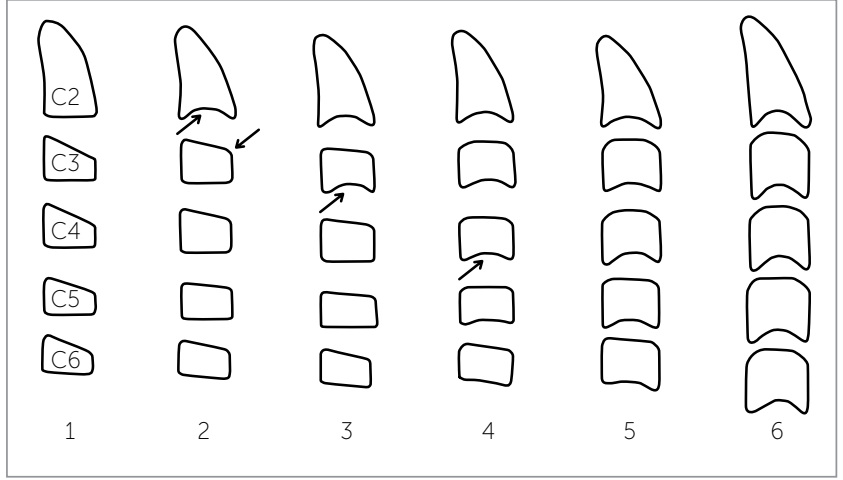

Figure 3 - Six stages of maturation of cervical vertebrae according to Hassel and Farman ${ }^{20}$.

outer portion of the nose to the beginning of the tail. The animals were weighed on a digital scale (Filizola BP15, Campo Grande, MS) in grams.

\section{Statistical analysis}

Normality test (Anderson-Darling, through Minitab 16 Software) was done and it was verified that the variables were normally distributed. Data were then tested for analysis of variance (ANOVA) and Pearson correlation.

\section{RESULTS}

Sequences of measurements and analysis of gradual length and weight

An increase in weight and length was observed for all animals (Tables 2 and 3).

Statistically significant differences were found between males and females in relation to weight. As expected, greater weight was found in males, when compared to females.

Three distinct phases could be observed:

1) Growth spurt from the weaning day to their $10-13^{\text {th }}$ week, when females and males respectively reached $250 \%$ and $350 \%$ of their initial weight.

2) Slow growth period: from $10-13^{\text {th }}$ to $27^{\text {th }}$ week.

3) Final growth phase: when males continued to gain weight, while females stabilized (Fig 4).

In relation to length, the first and second phases were very similar to the weight curve. In the growth spurt phase, the animals increased approximately $70 \%$ of their initial length. After that, increasing in length became slow and constant.

The final phase of growth was observed when losses or gains in weight were observed and length (Fig 5) was constant. The breeding phase began before the end of the growth in length and weight, corresponding to a month old. 
Table 2 - Mean body length and weight of females.

\begin{tabular}{|c|c|c|c|c|c|c|c|c|c|}
\hline & \multicolumn{9}{|c|}{ Days of life } \\
\hline & 22 & 37 & 52 & 67 & 97 & 127 & 157 & 187 & 217 \\
\hline Weight (g) & 87 & 125.03 & 190 & 231.33 & 357 & 405.66 & 454.33 & 500.66 & 511.66 \\
\hline Length (cm) & 13.85 & 16.13 & 18.82 & 20.73 & 23.16 & 24.23 & 24.86 & 25.36 & 26 \\
\hline
\end{tabular}

Table 3 - Mean body length and weight of males

\begin{tabular}{|c|c|c|c|c|c|c|c|c|c|}
\hline & \multicolumn{9}{|c|}{ Days of tife } \\
\hline & 22 & 37 & 52 & 67 & 97 & 127 & 157 & 187 & 217 \\
\hline Weight (g) & 87.5 & 154.4 & 206.5 & 235 & 273.2 & 279.8 & 285.5 & 317.5 & 317 \\
\hline Length $(\mathrm{cm})$ & 13.55 & 16.88 & 19.1 & 19.9 & 21.25 & 21.3 & 21.75 & 22 & 22.05 \\
\hline
\end{tabular}

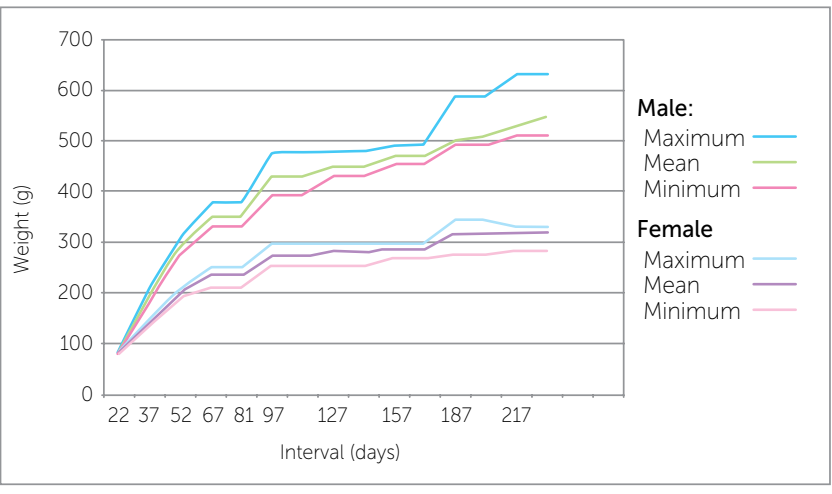

Figure 4 - Graphical representation of mean, minimum and maximum weight for females and males

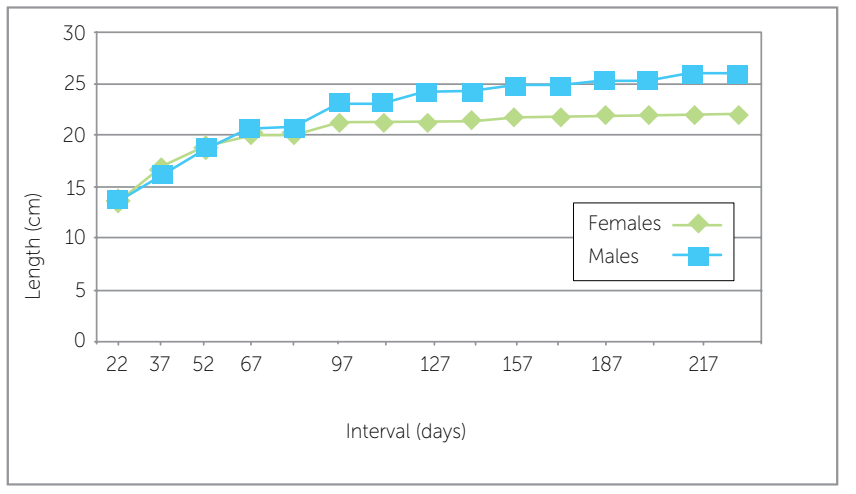

Figure 5 - Graphical representation of the mean length of females and males

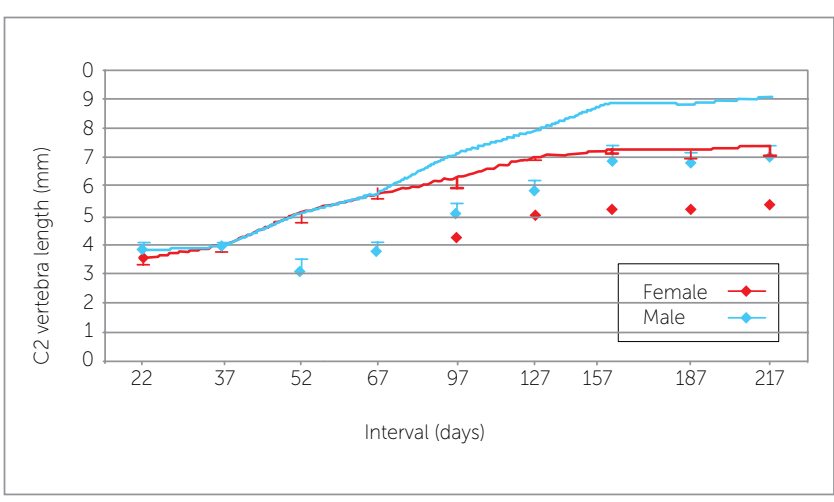

Figure 6 - Graphical representation of the growth of vertebra (C2)
Results of changes in cervical vertebrae of rats according to the Radio IMP software

Repeated Measures Analysis of Variance showed that males and females presented significant differences in height of the cervical vertebrae along the assessments $(p<0.001)$.

Cervical vertebrae showed statistically different values between days 22, 97, 127, 157, 187 and 217 ( $\mathrm{p}<0.001)$ but presented similar values on days $37(\mathrm{p}=0.5489), 52$ $(\mathrm{p}=0.9852)$ and $67(\mathrm{p}=0.7560)($ Fig 6$)$.

Increasing of the cervical vertebrae was relatively constant from weaning day to $22^{\text {nd }}$ week. After that, a stable phase was observed.

In relation to morphological changes, increasing in concavities on the bottom edge of the vertebrae of the animals was observed. From the radiographic exams, these changes allowed the differentiation of stages: Initial, growth spurt and final.

According to Pearson correlation, a high correlation $(r=0.86)$ was found between changes of cervical vertebrae and growth (increase in body length). The height and width of $\mathrm{C} 2$ and $\mathrm{C} 3$ vertebrae of rats increased along with growth.

\section{DISCUSSION}

In the present study, increasing in concavities on the bottom edge of the vertebrae of the animals was observed according to chronological age, consistent with studies about bone maturation in humans. ${ }^{4}$

While in humans, increasing of height of the vertebrae is observed during the entire period of growth regardless of sex, ${ }^{4}$ the present study presented higher values for males than females.

In rats, it was not possible to clearly identify the five or six stages as in studies of human cervical vertebrae. ${ }^{18,19}$ 
Even in humans, however, there are still some difficulties regarding the identification of the maturation stage. The comparison of three mostly used methods for cervical vertebrae in orthodontic patients shows that the determination of skeletal maturation stage via cervical vertebrae has satisfactory clinical applicability. ${ }^{25}$ However, it is also suggested modifications in order to facilitate the classification of the maturation stage.

Width measurements showed considerable oscillations, probably depending on the difficulty to position the rats during radiograph exam.

Even with the standardization of the position of the rats, a minimum of rotating or tilting the animal's head in relation to the body may have caused differences in measuring the widths of the cervical vertebrae, causing differences in the results.

It is suggested that among the cervical vertebrae, one should also be studied is the axis (first cervical vertebra) due to its relationship with the articular function and positioning of the head of the animal / patient.

Height measurements for vertebrae C2 and C3 increased according to body growth (increase in length and weight) in animals.

The existence of good correlation between the changes in the concavity of the lower border, height, and shape of cervical vertebrae in humans, ${ }^{26}$ in accordance to this study, suggests that these parameters are useful to evaluate maturation of cervical vertebrae.

Unlike what is expected in humans, however, there were no differences between rats with regard to body length and height of the vertebrae, which should be explained due to the environmental standardization and parity in the growth of animals.
The same strain, same food and space are factors that may have influenced the growth pattern of the animals, causing them to reach the same stability in the final period of growth.

In this context, we suggest a new study with different food and environment for observation of differences in growth and development between the animals.

The weight, especially in males, showed significant differences. Part of this difference in weight is due to fat accumulation. The length and weight of females was significantly smaller than males, even with the same food.

Comparisons between chronological and bone age show that in humans, there is a significant correlation between them. Besides that, the correlation is higher between radiographs of cervical vertebra and hand and wrist, than chronological age. ${ }^{27}$

Also regarding the relation between growth and the maturation of the vertebrae, as well as development of mandibular length and height, significant increments during growth are present for all parameters, demonstrating that the analysis of cervical vertebrae maturation is an appropriate method for assessing the mandibular bone maturity by the analysis of lateral cephalometric radiography. ${ }^{28}$

\section{CONCLUSIONS}

A high correlation was found between increasing in body length and weight, as well as in cervical vertebrae height.

Cervical vertebrae of rats showed growth in length, a slight increase in width and continuous development of concavities. However, it was not possible to clearly identify the five or six stages described in studies of cervical vertebrae maturation in humans. 
1. MCNamara JA Jr, Brudon WL. Tratamiento ortodóncico y ortopédico en la dentición mixta. 2a ed. Michigan: Needham; 1995

2. Armond MC. Estimativa do surto de crescimento puberal pela avaliação das vértebras cervicais em radiografias cefalométricas laterais [dissertação]. São José dos Campos (SP): Universidade Estadual Paulista Júlio de Mesquita Filho; 2000

3. Asumda FZ, Chase PB. Age-related changes in rat bone-marrow mesenchymal stem cell plasticity. BMC Cell Biol. 2011:12(1):44. Epub 2011 Oct 12

4. Tavano O, Freitas JAS, Lopes ES. Greulich \& Pyle e Tanner \& Whitehouse: comparação entre duas tabelas de avaliação de idade biológica através do desenvolvimento ósseo. Clin Pediatr. 1982;5(6):7-21.

5. Van der Linden FPG. Crescimento e Ortopedia Facial. 2ª ed. Rio de Janeiro: Quintessence: 1990.

6. Camargo GTL, Cunha TGE. Estudo do sincronismo entre o índice de maturação das vértebras cervicais, idade dentária e idade carpal com a idade cronológica. Sotau Rev Virtual Odontol. 2007:2(1):2-7.

7. Fishman LS. Radiographic evaluation of skeletal maturation: a clinically oriented method based on hand-wrist films. Angle Orthod. 1982 Abr:52(2):88-112.

8. Schusterchitz T, Haiter NF. Estudo comparativo entre maturação das vértebras cervicais e a região carpal. Ortod. 2002;35(3):33-42

9. Horliana RF. Estudo da relação entre os estágios de maturidade óssea avaliados em radiografias de mão e punho e das vértebras cervicais em telerradiografias em norma lateral [dissertação]. São Paulo (SP): Universidade de São Paulo; 2005.

10. Baccetti T, Franchi L, MCNamara Jr. JA. The cervical vertebral maturation (CVM) method for the assessment of optimal treatment timing in dentofacial orthopedics. Semin Orthod. 2005;11(3):119-29.

11. Paiva GAN, Barbosa RS, Ferreira EEM, Carvalho PEG, Ferreira RI. Avaliação radiográfica das vértebras cervicais como método para estimativa da maturidade esquelética. Ciênc Odontol Bras. 2007:10(1):54-63.

12. Grave B, Brown T, Townsend G. Comparison of cervicovertebral dimensions in Australian Aborigines and Caucasians. Eur J Orthod. 1999:21(2):127-35

13. Moraes MEL, Médici Filho E, Moraes LC. Surto de crescimento puberal: relação entre mineralização dentária, idade cronológica, idade dentária e idade óssea: método radiográfico. Rev Odontol UNESP. 1998:27(1):111-29.

14. Aguila JF, Berdasco A. Puberdade e maturação biológica. In: Aguila JF. Crescimento craniofacial. São Paulo: Pancast; 1997. p. 46-84
15. O'Reilly MT, Yanniello GJ. Mandibular growth changes and maturation of cervical vertebrae: a longitudinal cephalometric study. Angle Orthod. 1988;58(1-2):179-84

16. Ursi WJS. Crescimento das alterações mandibulares dos 6 aos 18 anos de idade. Rev Ortod. 1999:29(1):4-12

17. Greulich WW, Pyle SI. Radiographic atlas of skeletal development of hand and wrist. 2nd ed. California: Stanford University; 1971

18. Hägg $U$, Taranger J. Menarche and voice change as indicators of the pubertal growth spurt. Acta Odontol Scand. 1980;38(3):179-86

19. Franchi L, Baccetti T, MCNamara JA Jr. Mandibular growth as related to cervical vertebral maturation and body height. Am J Orthod Dentofacial Orthop. 2000;118(3):335-40.

20. Hassel B, Farman AG. Skeletal maturation evaluation using cervical vertebrae. Am J Orthod Dentofacial Orthop. 1995:107(1):58-66.

21. Santos CBN, Almeida RR, Henriques JFC, Bertoz FA, Almeida RR. Avaliação de um método de determinação do estágio de maturação esquelética utilizando as vértebras cervicais presentes nas telerradiografias em norma lateral. Rev Dental Press Ortod Ortop Facial. 1998:3(3):76-77.

22. Santos CBN, Almeida RR. Estudo comparativo de dois métodos de avaliação da idade esquelética utilizando telerradiografias em norma lateral e radiografias carpais. Ortodontia. 1999;32(2):33-45.

23. Adams N, Boice R. A longitudinal study of dominance in an outdoor colony of domestic rats. J Comp Psychol. 1983:97(1):24-33.

24. Ruth EB. Metamorphosis of the pubic symphysis. I. The white rat (Mus norvegicus albinus). Anat Rec. 1935;64:1-7.

25. Jaqueira LM, Armond MC, Pereira LJ, Alcântara CE, Marques LS Determining skeletal maturation stage using cervical vertebrae evaluation of three diagnostic methods. Braz Oral Res. 2010:24(4):433-7.

26. San Román P, Palma JC, Oteo MD, Nevado E. Skeletal maturation determined by cervical vertebrae development. Eur J Orthod. 2002:24(3):303-11

27. Litsas G, Ari-Demirkaya A. Growth indicators in orthodontic patients. Part 2: comparison of cervical bone age to hand-wrist skeletal age. Relationship with chronological age. Eur J Paediatr Dent. 2010:11(4):176-80

28. Baccetti T, Franchi L, McNamara Jr. JA. The cervical vertebral maturation method: some need for clarification. Am J Orthod Dentofacial Orthop. 2002:123(1):19A-20A 